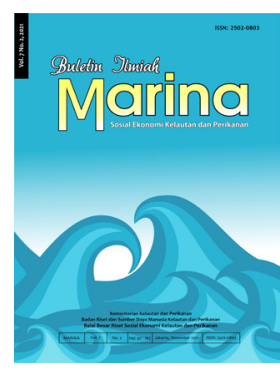

\author{
BULETIN ILMIAH MARINA \\ SOSIAL EKONOMI KELAUTAN DAN PERIKANAN \\ http://ejournal-balitbang.kkp.go.id/index.php/mra \\ p-ISSN: 2502-0803 \\ e-ISSN: $2541-2930$
}

Nomor Akreditasi: 10/E/KPT/2019

\title{
Strategi Pengembangan Usaha Budi Daya Rumput Laut (Eucheuma cottonii) di Daerah Perbatasan - Pulau Sebatik
}

\section{Development Strategy of Seaweed (Eucheuma cottonii) Cultivation in Border Area - Sebatik Island}

\author{
Syafrianto Sarmin, Muhammad Siri Dangnga, dan Andi Adam Malik ${ }^{*}$ \\ Program Pascasarjana Universitas Muhammadiyah Parepare \\ JIn. Jenderal Ahmad Yani Km. 6, Soreang, Pare-Pare 91112, Indonesia \\ Diterima tanggal: 18 Mei 2021; Diterima setelah perbaikan: 5 Desember 2021; \\ Disetujui terbit: 30 Desember 2021
}

\begin{abstract}
ABSTRAK
Usaha budi daya rumput laut berperan penting pada peningkatan kesejahteraan masyarakat dan penyerapan tenaga kerja di daerah perbatasan Pulau Sebatik. Pembudi daya rumput laut menghadapi beberapa permasalahan, antara lain, permodalan, biaya produksi, permintaan pasar yang tidak stabil, akses informasi pasar, dan faktor kesehatan. Pembudi daya rumput laut juga berprofesi sebagai nelayan, pegawai, dan pedagang yang belum memiliki cukup pengetahuan dan keterampilan tentang teknis budi daya rumput laut. Penelitian ini bertujuan menganalisis tingkat kelayakan finansial dan strategi pengembangan usaha budi daya rumput laut di Pulau Sebatik. Pelaksanaan penelitian ini dilaksanakan pada bulan Mei 2018 sampai Agustus 2019. Sampel dalam penelitian yang dipilih secara purposive (sengaja) terdiri dari 47 pelaku usaha budi daya rumput laut dan pihak-pihak yang terkait dengan usaha budi daya rumput laut, yaitu Dinas Perikanan, Badan Pusat Statistik, tenaga pendamping teknis perikanan, Camat Kecamatan Sebatik Barat, dan pedagang pengumpul. Data dianalisis menggunakan metode analisis finansial meliputi NPV, IRR, R/C Ratio, BEP, PBP, dan analisis SWOT. Hasil analisis finansial menunjukkan bahwa usaha budi daya rumput laut di Pulau Sebatik layak untuk dijalankan dengan perolehan NPV sebesar Rp32.004.226,58; IRR sebesar 12,12\%; R/C Ratio sebesar 1,82; dan PP sebesar 3,9 tahun. Strategi yang diprioritaskan untuk diimplementasikan adalah meningkatkan dukungan pemerintah dalam kebijakan pemasaran dan perkembangan teknologi, mengadakan bibit varietas baru, serta mengoptimalkan ketersediaan tenaga kerja dan ketersediaan lahan yang didukung sumber daya yang terampil.
\end{abstract}

Kata kunci: kelayakan finansial; strategi; pengembangan; rumput laut; analisis SWOT

\begin{abstract}
Seaweed cultivation business plays an important role in improving community welfare and employment on Sebatik Island. However, the seaweed farmers commonly faced problems, namely, financial capital, production costs, unstable market demand, access to market information, and health factors. Moreover, these seaweed farmers also have other jobs such as fishermen, employees, traders who do not have enough knowledge and skills for seaweed cultivation. This study aims to analyze the financial feasibility and determine the strategy for developing seaweed cultivation in Sebatik Island. The implementation of this research was carried out from May 2018 to August 2019. This research consisted of 47 seaweed cultivation business actors and parties related to the business, namely the Fisheries Services, Central Statistics Bureau, fishery technical assistants, Subdistrict Head of West Sebatik Subdistrict, and traders that were selected purposively. Data were analyzed using financial analysis methods including NPV, IRR, R/C Ratio, BEP, PP, and SWOT analysis. The financial analysis results showed that the seaweed farming business on Sebatik Island was feasible to run with the acquisition of an NPV Rp32,004,226.58, IRR 12.12\%, R/C Ratio 1.82, and PP 3,9 years. The prioritized strategies to be
\end{abstract}


implemented are increasing government support in marketing policies and technological developments, procuring new varieties of seeds, and optimizing the availability of labor and land availability supported by skilled resources.

\section{Keywords: financial feasibility; strategy; development; seaweed; SWOT analysis}

\section{PENDAHULUAN}

\section{Latar Belakang}

Kesuksesan beberapa negara dalam pembangunan sektor kelautan dan perikanan, seperti Islandia, Norwegia, Thailand, dan Korea Selatan menjadi landasan pentingnya pembangunan sektor kelautan dan perikanan di Indonesia. Pembangunan kelautan dan perikanan di beberapa negara tersebut dapat berperan dalam peningkatan kesejahteraan rakyat, menyerap tenaga kerja, serta menumbuhkan ekonomi. Potensi sumber daya kelautan dan perikanan yang demikian besar menjadikan sektor kelautan dan perikanan sebagai penggerak utama pembangunan ekonomi nasional. Sektor kelautan dan perikanan sepatutnya dijadikan arus utama (mainstream) pembangunan nasional (Departemen Kelautan dan Perikanan, 2006).

Kabupaten Nunukan berada pada wilayah utara Provinsi Kalimantan Utara yang berbatasan langsung dengan Negara Malaysia. Kabupaten Nunukan memiliki luas wilayah sebesar 14.263,68 $\mathrm{km}^{2}$ dan memiliki wilayah lautan seluas $1.408,758$ $\mathrm{km}^{2}$ sejauh 4 mil dari garis pantai terluar ke arah laut (Dinas Kelautan dan Perikanan Kabupaten Nunukan, 2015). Pulau Sebatik adalah salah satu pulau terluar dari wilayah NKRI, yang ditetapkan oleh pemerintah sebagai salah satu lokasi minapolitan di Indonesia (Keputusan Menteri Kelautan dan Perikanan No.KEP.32/MEN/2010). Pada perkembangannya, kegiatan budi daya rumput laut di Kabupaten Nunukan mengalami kemajuan pesat. Pembudi daya menggunakan jenis rumput laut Eucheuma cottonii untuk dibudidayakan di perairan Selat Sebatik dan perairan Pulau Nunukan (Shafitri et al., 2020). Berkembangnya usaha budi daya rumput laut di Kabupaten Nunukan dan didukung oleh peluang ekonomi, menyebabkan adanya transformasi pekerjaan. Masyarakat nelayan yang dulu bekerja sebagai nelayan, sekarang mempunyai alternatif mata pencaharian dengan usaha budi daya rumput laut (Wijaya \& Sari, 2018).

Pembudi daya rumput laut menggunakan sistem longline dengan hasil panen rumput laut yang bervariasi. Pembudi daya rumput laut dapat menghasilkan bobot panen sekitar 13-15 kg setiap satu bentangan pada musim puncak. Sementara itu, pada kondisi musim tanam kurang bagus, satu bentangan hanya menghasilkan sekitar $5 \mathrm{~kg}$. Pemeliharaan rumput laut membutuhkan waktu sekitar 45 hari per siklus tanam, kadang-kadang 50 hari karena kurangnya prasarana penjemuran rumput laut. Secara kuantitas, peningkatan jumlah produksi diikuti dengan meningkatnya luas kawasan budi daya. Produksi rumput laut Kabupaten Nunukan mencapai 3.000 ton kering/ bulan, dan Pulau Sebatik berkontribusi produksi sebesar 30\% (Radiarta et al., 2016). Menurutnya, mengembangkan budi daya rumput laut adalah langkah operasional yang perlu dilakukan untuk membangun kemandirian dalam budi daya perikanan. Potensi pasar yang luas dan masih minimnya usaha budi daya rumput laut memberikan peluang yang cerah di masa mendatang untuk dikembangkan (Antowijoyo et al., 2017).

Usaha budi daya rumput laut menguntungkan dan layak untuk diusahakan (Wahyuni et al., 2021; Irmayani et al., 2014; Paramita \& Syachbrani, 2019; Risdiansyah, 2011; Lukman et al., 2019; Ngamel, 2012). Meskipun usaha budi daya rumput laut ini menguntungkan, ada beberapa kendala dalam proses produksinya, antara lain, minimnya modal yang dimiliki oleh sebagian pembudi daya. Biaya produksi yang semakin meningkat diakibatkan oleh kurangnya tenaga kerja, pemasaran yang tidak stabil menyebabkan terjadinya permainan pasar yang dilakukan oleh penadah dengan cara menentukan tinggi rendahnya harga beli pada pembudi daya, akses informasi pasar yang masih lemah mengakibatkan pemasaran rumput laut masih dikuasai penuh oleh pedagang pengumpul. Hal ini dapat mengurangi aktivitas produksi rumput laut (Reski, 2013). Strategi pengembangan rumput laut Eucheuma cottonii telah banyak dilakukan di beberapa lokasi di perairan Indonesia seperti yang dikaji oleh Putri et al., (2014); Suryawati dan Erlina, 2017); Nurdin et al. (2013); Patang (2014); Hadifa et al. (2017); serta Pandelaki (2012).

Analisis kelayakan finansial dan perumusan strategi pengembangan usaha yang tepat untuk 
dapat diterapkan agar usaha budi daya rumput laut yang dikembangkan di Pulau Sebatik Kabupaten Nunukan dapat dilakukan secara berkelanjutan. Oleh karena itu, riset ini bertujuan untuk mengetahui tingkat kelayakan finansial dan menentukan strategi pengembangan usaha budi daya rumput laut (Eucheuma cottonii) di daerah perbatasan di Pulau Sebatik.

\section{Pendekatan IImiah}

Pelaksanaan penelitian ini dimulai pada bulan Mei 2018 sampai Agustus 2019 di Pulau Sebatik Kabupaten Nunukan Propinsi Kalimantan Utara. Pemilihan lokasi penelitian dilakukan dengan pertimbangan bahwa pengembangan usaha budi daya rumput laut mulai terus berkurang seiring berjalannya waktu. Faktor alam yang baik seperti kondisi air laut yang mendukung pertumbuhan rumput laut, kondisi lahan untuk produksi rumput laut masih sangat memadai perlu mengembangkan usaha budi daya rumput laut

Penelitian ini dilakukan dengan metode deskriptif kualitatif dan kuantitatif dengan menggambarkan instrumen kuesioner dan wawancara (Arikunto, 2002). Berdasarkan data dari Badan Pusat Statistik Kabupaten Nunukan, jumlah populasi penelitian adalah warga rumah tangga perikanan budi daya rumput laut di Pulau Sebatik, yaitu 394. Sampel yang diambil adalah $12 \% \times 394$ jumlah populasi $=47$ warga rumah tangga perikanan budi daya rumput laut. Data yang dikumpulkan dari responden pembudi daya adalah data primer yang merupakan data yang diperoleh langsung dari lapangan berdasarkan pengamatan langsung, wawancara, dan diskusi dengan responden dan narasumber (Arikunto, 2002). Data sekunder diperoleh dari Dinas Pertanian, Ketahanan Pangan dan Perikanan serta data yang diambil dari Badan Pusat Statistik berupa jumlah populasi, letak geografis, keadaan penduduk, dan instansi yang terkait dengan penelitian ini. Metode pengumpulan data pada penelitian ini dilakukan dengan cara pengamatan, wawancara, dan participatory rapid appraisal (PRA) (Al Amin, 2011).

Ada 2 model analisis data yang digunakan pada penelitian ini, yaitu

\section{Analisis Finansial}

- Net Present Value (NPV) $N P V=\sum_{\mathrm{i}=0}^{\mathrm{t}=\mathrm{n}} \frac{\mathrm{Bt}-\mathrm{Ct}}{(1+\mathrm{i})^{\mathrm{t}}} \ldots$ (Pasaribu et al., 2005) atau
$N P V=\sum_{i=0}^{t=n}(\mathrm{Bt}-\mathrm{Ct})(\mathrm{DF})$

Kriteria:

NPV $>0$, maka proyek suatu usaha menguntungkan $\mathrm{NPV}=0$, maka proyek tidak untung dan tidak rugi $\mathrm{NPV}<0$, maka proyek suatu usaha merugikan

- Internal Rate of Return (IRR)

$\operatorname{IRR}=i^{\prime}+\frac{N P V^{\prime}}{N P V^{\prime}-N P V^{\prime \prime}}\left(i^{\prime \prime}-i^{\prime}\right)$ (Pasaribu et al.,2005)

Kriteria:

IRR > tingkat suku bunga yang berlaku, maka usaha layak untuk dikembangkan

IRR < tingkat suku bunga yang berlaku, maka usaha tidak layak dikembangkan

- Net Revenuew Cost Ratio (R/C Ratio)

Menurut Soekartawi (2003), Net

Revenuew Cost Ratio dapat dihitung dengan menggunakan rumus :

$\frac{R}{C}$ Ratio $=\frac{\text { TotalPenerimaan }}{\text { TotalCost }}$

Kriteria :

Net $R / C>0$, maka usaha layak untuk dilanjutkan

Net $R / C=0$, maka usaha impas

Net $R / C<0$, maka usaha tidak layak untuk dikembangkan

- Break Event Point (BEP)/Titik Impas

Menurut, BEP dapat dihitung dengan dua cara dengan rumus dari Riyanto (2010) yaitu Atas dasar penjualan dalam unit:

$B E P($ unit $)=\frac{F C}{(P-V C)}$

Atas dasar penjualan dalam rupiah:

$B E P(R p)=\frac{F C}{1-\frac{V C}{T R}}$

Keterangan:

$\mathrm{FC}=$ Biaya Tetap $(\mathrm{Rp})$

$\mathrm{VC}=$ Biaya Variabel $(\mathrm{Rp})$

$\mathrm{TR}=$ Total Penerimaan $(\mathrm{Rp})$

\section{- Payback Period}

Payback Period (PP) dapat dihitung dengan menggunakan rumus berikut (Soekartawi, 2003):

$$
P P=\frac{T C}{\text { Laba PerPanen }}
$$

Keterangan:

$\mathrm{TC}=$ Total Investasi 


\section{Analisis SWOT}

Metode analisis yang dilakukan pada analisis SWOT adalah menganalisis faktor internal dan eksternal, perhitungan skor faktor internal dan eksternal, analisis matriks IE, analisis matriks space, matriks grand strategy, matriks SWOT strategi pengembangan dan tahap keputusan untuk menentukan strategi yang diprioritaskan untuk diimplementasikan pada proses pengembangan usaha budi daya rumput laut. Analisis SWOT merupakan analisis kualitatif untuk mengidentifikasi berbagai faktor secara sistematis dan memformulasikan strategi suatu kegiatan. Analisis ini didasarkan pada logika yang memaksimalkan kekuatan (strengths) dan peluang (opportunities), namun secara bersamaan dapat meminimalkan kelemahan (weakness) dan ancaman (threats) (Rangkuti, 2008).

Pemberian bobot (nilai) dilakukan terhadap setiap unsur SWOT berdasarkan tingkat kepentingan dan kondisi kawasan atau wilayah untuk menetukan kebijakan yang terbaik. Bobot atau nilai yang diberikan berkisar $1-3$. Unsur kekuatan dan peluang diberi nilai 1 berarti tidak penting/tidak besar, 2 berarti penting/besar, dan 3 berarti sangat penting/sangat besar. Unsur kelemahan dan ancaman diberi nilai sebaliknya, yaitu 1 sangat penting/sangat besar, 2 berarti penting/besar, dan 3 berarti tidak penting/tidak besar. Setelah masing-masing unsur SWOT diberi bobot atau nilai, unsur-unsur tersebut dihubungkan keterkaitannya untuk memperoleh beberapa strategi pengembangan (SO, ST, WO, dan WT). Bobot setiap strategi tersebut dijumlahkan untuk menghasilkan rangking strategi (Hartati, 2003).

Strategi yang dihasilkan terdiri dari beberapa alternatif strategi. Untuk menentukan prioritas strategi yang harus dipilih, maka dilakukan penjumlahan bobot yang berasal dari keterkaitan antara unsur-unsur kekuatan, kelemahan, peluang, dan ancaman yang terdapat dalam alternatif strategi. Jumlah bobot akan menentukan rangking prioritas alternatif strategi pengembangan berkelanjutan budi daya rumput laut. Jumlah bobot yang paling tinggi dipilih sebagai strategi yang paling prioritas untuk dilakukan, sehingga pada akhirnya dapat meningkatkan kesejahteraan para petani pembudi daya khususnya dan masyarakat pesisir pada umumnya (Hartati, 2003). Teknik analisis yang didesain dalam membuat peringkat strategi yang digunakan untuk menghasilkan daftar prioritas dan menentukan daya tarik relatif dari alternatif tindkan yang layak. Teknik ini adalah matriks perencanaan strategi kuantitatif atau quantitatif strategy planning matrix (QSPM).

\section{KELAYAKAN USAHA BUDI DAYA RUMPUT LAUT}

\section{Biaya Tidak Tetap (Variable Cost)}

Pengeluaran biaya tidak tetap pada usaha budi daya rumput laut di Pulau Sebatik mengikuti banyaknya tali bentangan yang dipasang setiap kali proses produksi. Semakin banyak jumlah tali bentangan yang dipasang oleh pembudi daya maka biaya tidak tetap akan semakin tinggi (Tabel 1).

\section{Biaya Tetap (Fixed Cost)}

Biaya tetap adalah biaya yang harus dikeluarkan oleh pembudi daya rumput laut di Pulau Sebatik dan tidak berpengaruh terhadap tingkat produksi. Rata-rata biaya tetap yang dikeluarkan oleh responden adalah nilai penyusutan alat yang digunakan disajikan pada Tabel 2 .

\section{Pendapatan Usaha Budi Daya Rumput Laut}

Jumlah produksi yang dihasilkan dalam suatu kegiatan usaha dikalikan dengan harga yang berlaku di pasar disebut penerimaan usaha budi daya rumput laut. Sedangkan pendapatan bersih (net income) yang diperoleh pembudi daya rumput laut dikurang dengan total biaya yang dikeluarkan per musim tanam adalah pendapatan usaha budi daya rumput laut (Soekartawi, 2003). Adapun jumlah pendapatan pada usaha budi daya rumput laut di Pulau Sebatik disajikan pada Tabel 3.

\section{Analisis Kelayakan Finansial Usaha Budi Daya Rumput Laut}

Analisis kelayakan usaha pada usaha budi daya adalah bertujuan untuk mengukur tingkat kelayakan suatu usaha yang dijalankan oleh pembudi daya. Dalam proses analisis kelayakan, metode yang digunakan pada usaha budi daya rumput laut di Pulau Sebatik adalah metode penilaian investasi yang meliputi Net Present Value (NPV), Internal Rate of Return (IRR), R/C Ratio, Break Event Point (BEP), dan Payback of Period (PBP). Hasil analisis kelayakan disajikan dalam Tabel 4.

Net Present Value (NPV) merupakan 
Tabel 1. Rata-rata Biaya Variabel pada Usaha Budi Daya Rumput Laut di Pulau Sebatik.

\begin{tabular}{|c|c|c|c|c|c|}
\hline Biaya Variabel & & Jumlah & $\begin{array}{l}\text { Harga Satuan } \\
\text { (Rp) }\end{array}$ & Nilai (Rp) & $\begin{array}{c}\text { Persentase } \\
(\%)\end{array}$ \\
\hline Tenaga Kerja & & & & 2.236 .170 & 75,38 \\
\hline - Upah Mengikat Bibit & 204 & Tali & 10.000 & 2.036.170 & \\
\hline - Upah Menanam Bibit & 1 & Orang & 100.000 & 100.000 & \\
\hline - Upah Panen & 1 & Orang & 100.000 & 100.000 & \\
\hline Tranportasi & & & & 437.871 & 14,76 \\
\hline - BBM Pengambilan Bibit & & & & 145.957 & \\
\hline - BBM Penanaman Bibit & & & & 145.957 & \\
\hline - BBM Panen & & & & 145.957 & \\
\hline Konsumsi & & & & 292.554 & 9,86 \\
\hline Konsumsi Tanam Bibit & & & & 146.277 & \\
\hline Konsumsi Panen & & & & 146.277 & \\
\hline Total & & & & $2.966 .595,74$ & 100,00 \\
\hline
\end{tabular}

Sumber : Data Primer Diolah, 2019

Tabel 2. Rata-rata Biaya Penyusutan Pembudi Daya Responden pada Usaha Budi Daya Rumput Laut di Pulau Sebatik, Kalimantan Utara.

\begin{tabular}{|c|c|c|c|c|}
\hline Nama Barang & Nilai Awal (Rp) & $\begin{array}{l}\text { Nilai Akhir } \\
\text { (Rp) }\end{array}$ & $\begin{array}{l}\text { Umur } \\
\text { Ekonomis } \\
\text { (Tahun) }\end{array}$ & $\begin{array}{l}\text { Biaya Penyusutan } \\
\text { (Rp/tahun) }\end{array}$ \\
\hline Pondasi Penanaman & $20.893 .617,00$ & $6.110 .638,00$ & 5 & $2.956 .596,00$ \\
\hline Tali Bentangan & $9.872 .340,00$ & $3.543 .617,00$ & 5 & $1.265 .745,00$ \\
\hline Pelampung Jerigen & $689.574,00$ & - & 2,5 & $275.830,00$ \\
\hline Pelampung Botol & $3.156 .383,00$ & - & 2,5 & $1.275 .319,00$ \\
\hline Terpal & $1.392 .128,00$ & - & 2 & $696.064,00$ \\
\hline Perahu & $37.962 .963,00$ & $9.555 .556,00$ & 9 & $3.051 .852,00$ \\
\hline Lantai Jemur & $20.777 .778,00$ & $2.417 .778,00$ & 9 & $1.987 .345,00$ \\
\hline Pisau & $50.000,00$ & - & 5 & $10.000,00$ \\
\hline Garpu Penjemur & $100.000,00$ & - & 5 & $20.000,00$ \\
\hline \multicolumn{4}{|c|}{ Jumlah Biaya Penyusutan dalam 1 Tahun } & $11.538 .751,00$ \\
\hline \multicolumn{4}{|c|}{ Jumlah Biaya Penyusutan dalam 1 Kali Produksi } & $961.563,00$ \\
\hline
\end{tabular}

Sumber: Data Primer Diolah, 2018

Tabel 3. Rata-rata Penerimaan, Biaya Produksi, dan Pendapatan Pembudi Daya (Responden) pada Usaha Budi Daya Rumput Laut di Pulau Sebatik, Kalimantan Utara.

\begin{tabular}{|c|c|c|c|c|}
\hline & Uraian & $\begin{array}{l}\text { Nilai Aktual Per } \\
\text { Produksi }\end{array}$ & $\begin{array}{c}\text { Jumlah Produksi } \\
\text { (1 Tahun) }\end{array}$ & $\begin{array}{l}\text { Nilai Dikonversi } \\
\text { produksi Pertahun }\end{array}$ \\
\hline \multirow[t]{4}{*}{1} & Penerimaan & & & \\
\hline & - Produksi (Kg) & 524,68 & 6 & $3.148,08$ \\
\hline & - Harga Jual (Rp/Kg) & $17.000,00$ & & 17.000 \\
\hline & Rata-rata Penerimaan & Rp8.919.574,00 & & Rp53.517.444,00 \\
\hline \multirow[t]{4}{*}{2} & Biaya Produksi & & & \\
\hline & - Biaya Variabel & Rp2.966.595,74 & 6 & Rp17.799.574,44 \\
\hline & - Biaya Tetap & & & Rp11.538.750,53 \\
\hline & Total Biaya Produksi & & & Rp29.338.324,97 \\
\hline 3 & Pendapatan Bersih & & & Rp24.179.119,03 \\
\hline
\end{tabular}

Sumber: Data Primer Diolah, 2018 
manfaat bersih yang diterima oleh pembudi daya selama umur usaha budi daya rumput laut dengan tingkat discount rate tertentu. Hasil analisis nilai $\mathrm{Net}$ Present Value (NPV) pada usaha budi daya rumput laut di Pulau Sebatik sebesar Rp32.004.226,58 menunjukkan bahwa usaha tersebut memberikan manfaat yang positif pada tingkat suku bunga $6 \%$ sehingga memberikan kepastian bahwa usaha budi daya rumput laut di Pulau Sebatik dapat dilanjutkan. Nilai Net Present Value (NPV) pada usaha budi daya rumput laut di Pulau Sebatik lebih kecil dibandingkan dengan nilai Net Present Value (NPV) pada usaha budi daya rumput laut di wilayah pesisir Kecamatan Teluk Pandan Kabupaten Kutai Timur karena produksi rumput laut di wilayah pesisir Kecamatan Teluk Pandan Kabupaten Kutai Timur yang besar dibandingkan dengan produksi usaha budi daya rumput laut di Pulau Sebatik sehingga memberikan pendapatan yang besar pula (Radiarta et al., 2016; Kailola et al., 2016; Reski, 2013).

Tabel 4. Hasil Analisis Kelayakan Finansial Usaha Budi Daya Rumput Laut di Pulau Sebatik, Kalimantan Utara.

\begin{tabular}{clr} 
No & \multicolumn{1}{c}{ Kriteria Investasi } & \multicolumn{1}{c}{ Nilai } \\
\hline 1 & Net Present Value (NPV) & Rp32.004.226,58 \\
2 & $\begin{array}{l}\text { Internal Rate of Return } \\
\text { (IRR) }\end{array}$ & $12,12 \%$ \\
3 & R/C Ratio & 1,82 \\
4 & $\begin{array}{l}\text { Break Event Point (BEP) } \\
\text { Unit (kg) }\end{array}$ & $1.725,78$ \\
5 & $\begin{array}{l}\text { Break Event Point (BEP) } \\
\text { Nilai (Rp) }\end{array}$ & Rp 29.338.324,97 \\
6 & Payback Period (PBP) & 3,9
\end{tabular}

Sumber: Data Primer Diolah, 2018

Internal Rate of Return (IRR) adalah indikator efisiensi dari suatu investasi. Hasil dari analisis Internal Rate of Return (IRR) menyampaikan bahwa investasi yang dilakukan pada suatu usaha dalam keadaan efisien apabila menunjukkan hasil analisis yang lebih tinggi dari tingkat suku bunga yang berlaku. Hasil analisis Internal Rate of Return (IRR) usaha budi daya rumput laut di Pulau Sebatik, diperoleh $12,12 \%$ yang membuktikan bahwa hasil tersebut masih lebih menguntungkan daripada disimpan di bank dengan tingkat suku bunga sampai $12,12 \%$, berarti investasi pada usaha budi daya rumput laut layak untuk dijalankan (Nur et al., 2019).

Analisis R/C Ratio merupakan perbandingan antara pendapatan atau penerimaan bersih dengan total biaya. Hasil analisis dari R/C Ratio mencerminkan berapa rasio keuntungan yang diperoleh pembudi daya sehingga dapat ditentukan layak atau tidaknya suatu usaha dijalankan. R/C Ratio usaha budi daya rumput laut di Pulau Sebatik adalah sebesar 1,82. R/C Ratio pada usaha budi daya rumput laut di Pulau Sebatik lebih tinggi dari R/C Ratio pada usaha budi daya rumput laut di Kabupaten Jeneponto sebesar 1,79 (Irmayani et al., 2014). Hal ini dapat terjadi karena rata-rata jumlah selisih antara penerimaan dan total biaya pada usaha budi daya rumput laut di Pulau Sebatik lebih besar dari jumlah selisih antara penerimaan dan total biaya pada usaha budi daya rumput laut di Kabupaten Jeneponto. R/C Ratio pada usaha budi daya rumput laut di Pulau Sebatik lebih besar dari 1 yang membuktikan bahwa usaha ini dalam kategori layak untuk dikembangkan. Setiap pengeluaran Rp1,00 akan menghasilkan keuntungan sebesar Rp1,82 dalam proses produksi rumput laut.

Break Event Point (BEP) merupakan analisis yang digunakan untuk mengetahui titik impas pada suatu usaha budi daya rumput laut dan terdapat 2 jenis titik impas, yaitu titik impas unit $(\mathrm{kg})$ dan titik impas nilai. Hasil analisis Break Event Point (BEP) unit pada usaha budi daya rumput laut di Pulau Sebatik sebanyak $1.725,78 \mathrm{~kg}$ menunjukkan bahwa titik impas pada usaha budi daya rumput laut di Pulau Sebatik pembudi daya tercapai di saat produksi tiap tahun mencapai 1.725,78 kg. Hasil analisis Break Event Point (BEP) nilai pada usaha budi daya rumput laut di Pulau Sebatik sebesar Rp29.338.324,97. Hal ini menunjukkan bahwa titik impas pada usaha budi daya rumput laut di Pulau Sebatik tercapai dalam satu tahun sebesar Rp29.338.324,97. Hal ini searah dengan hasil penelitian (Marak et al,. 2018)

Payback Period (PP) adalah analisis yang menentukan berapa lama masa produksi rumput laut untuk mengembalikan modal atau investasi usaha pada usaha budi daya rumput laut. Nilai Payback Period (PP) dari analisis usaha budi daya rumput laut di Pulau Sebatik adalah 3,9 tahun yang berarti pembudi daya dapat mengembalikan modal usaha atau investasi dalam jangka waktu tiga tahun sembilan bulan, sehingga usaha ini berpeluang dan layak untuk dilanjutkan (Marak et al. 2018).

\section{STRATEGI PENGEMBANGAN USAHA BUDI DAYA RUMPUT LAUT}

Analisis SWOT berperan dalam penetapan beberapa strategi dengan metode perbandingan antara faktor eksternal usaha budi daya rumput 
laut berupa peluang dan ancaman dengan faktor internal usaha berupa kekuatan serta kelemahan usaha (Tabel 5).

Alternatif strategi pengembangan yang dihasilkan diuraikan sebagai berikut :

\section{1) Strategi SO (Strengths - Opportunities)}

Strategi SO merupakan strategi yang disusun berdasarkan pertimbangan-pertimbangan faktor kekuatan (Strengths) yang dimiliki oleh usaha dengan peluang (Opportunities) yang datang dari luar usaha yang selanjutnya digunakan untuk mengembangkan usaha budi daya rumput laut di Pulau Sebatik.

Berdasarkan pertimbangan dari 10 faktor yang ada, dihasilkan 2 alternatif strategi yang

Tabel 5. Matriks SWOT pada Usaha Budi Daya Rumput Laut di Pulau Sebatik.

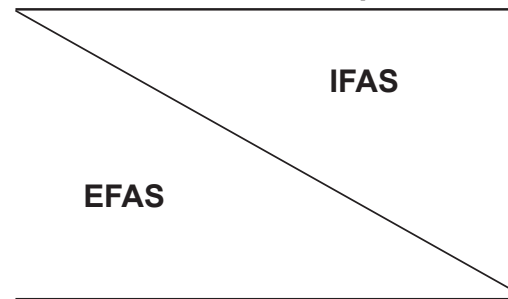

Peluang (Opportunities $/ 0$ )

1. Peningkatan kesejahteraan masyarakat

2. Adanya industri rumput laut

3. Perkembangan teknologi

4. Pasar terbuka luas

5. Kebutuhan konsumsi rumput laut yang semakin meningkat

\section{Kekuatan (Strengths/S)}

1. Ketersediaan tenaga kerja

2. Pemasaran mudah

3. Ketersediaan lahan

4. Memiliki sumber daya yang trampil

5. Dukungan pemerintah

\section{Kelemahan (Weaknessess/W)}

1. Bibit kurang sehat

2. Ketersediaan bibit baru

3. Teknologi budi daya

4. Kelembagaan pembudi daya

5. Ketersediaan modal
1. Mengoptimalkan ketersediaan tenaga kerja dan ketersediaan lahan yang didukung sumber daya yang terampil untuk meningkatkan jumlah produksi sehingga dapat memenuhi kebutuhan konsumen yang semakin meningkat.

2. Meningkatkan dukungan pemerintah dalam kebijakan pemasaran dan perkembangan teknologi sehingga pasar semakin terbuka luas dan meningkatkan jumlah produksi industri rumput laut dapat masuk untuk memenuhi peningkatan kesejahteraan masyarakat.

\footnotetext{
Ancaman (Threats/T)

1. Fluktuasi harga

2. Jatuhnya harga jual

3. Penyakit gatal-gatal pada pembudi daya

4. Arus laut deras dan ombak besar pada bulan tertentu

5. Serangan hama lumut dan tiram
}

1. Mengadakan bibit varietas baru yang ditemukan melalui teknologi yang mutakhir untuk mengatasi bibit yang kurang sehat sehingga meningkatkan kualitas dan jumlah produksi serta memiliki pangsa pasar luas yang berdampak pada peningkatan kesejahteraan pembudi daya rumput laut.

2. Mengoptimalkan kelembagaan pembudi daya untuk menciptakan kerjasama dalam mengatasi masalah ketersediaan modal sehingga terjadi peningkatan jumlah produksi untuk memenuhi kebutuhan konsumsi.

\section{Meningkatkan dukungan} SDM yang terampil melalui pelatihan dan penyuluhan untuk mengatasi ancaman arus laut dan ombak besar pada bulan tertentu dan mengatasi ancaman serangan hama lumut dan tiram.

2. Meningkatkan dukungan pemerintah melalui sosialisasi kesehatan untuk mengatasi ancaman penyakit gatal-gatal pada pembudi daya dan melalui pelatihan/ penyuluhan peningkatan kualitas produk serta manajemen pasar sehingga mampu menghindari ancaman fluktuasi harga dan jatuhnya harga jual.

\section{Strategi WT}

1. Adanya bibit varietas baru untuk mengatasi serangan hama lumut dan tiram serta mampu bertahan terhadap arus laut dan guncangan ombak yang besar sehingga penyakit gatal-gatal pada pembudi daya yang disebabkan oleh lumut dapat teratasi.

2. Mengoptimalkan kelembagaan pembudi daya sebagai wadah penghubung dengan instansi terkait untuk menetapkan kebijakan tentang standar harga sehingga ancaman fluktuasi harga dan jatuhnya harga jual dapat diatasi. 
layak, yaitu: (1) Mengoptimalkan ketersediaan tenaga kerja dan ketersediaan lahan yang didukung sumber daya yang terampil untuk meningkatkan jumlah produksi sehingga dapat memenuhi kebutuhan konsumen yang semakin meningkat; (2) Meningkatkan dukungan pemerintah dalam kebijakan pemasaran dan perkembangan teknologi sehingga pasar semakin terbuka luas dan meningkatkan jumlah produksi industri rumput laut dapat masuk untuk memenuhi peningkatan kesejahteraan masyarakat.

\section{2) Strategi WO (Weaknesess - Opportunities)}

Strategi WO merupakan strategi yang disusun berdasarkan pertimbangan-pertimbangan faktor kelemahan (Weaknesess) yang dimiliki oleh usaha dengan peluang (Opportunities) yang datang dari luar usaha yang selanjutnya digunakan untuk mengembangkan usaha budi daya rumput laut di Pulau Sebatik.

Berdasarkan pertimbangan dari 10 faktor yang ada, dihasilkan 2 alternatif strategi yang layak, yaitu: (1) Mengadakan bibit varietas baru yang ditemukan melalui teknologi yang mutakhir untuk mengatasi bibit yang kurang sehat sehingga meningkatkan kualitas dan jumlah produksi serta memiliki pangsa pasar luas yang berdampak pada peningkatan kesejahteraan pembudi daya rumput laut, (2) Mengoptimalkan kelembagaan pembudi daya untuk menciptakan kerja sama dalam mengatasi masalah ketersediaan modal sehingga terjadi peningkatan jumlah produksi untuk memenuhi kebutuhan konsumsi.

\section{3) Strategi ST (Strengths - Threats)}

Strategi ST merupakan strategi yang disusun berdasarkan pertimbangan-pertimbangan faktor kekuatan (Strengths) yang dimiliki oleh usaha dengan ancaman (Threats) yang datang dari luar usaha yang selanjutnya digunakan untuk mengembang usaha budi daya rumput laut di Pulau Sebatik.

Berdasarkan pertimbangan dari 10 faktor yang ada, dihasilkan 2 alternatif strategi yang layak, yaitu : (1), Meningkatkan dukungan SDM yang terampil melalui pelatihan dan penyuluhan untuk mengatasi ancaman arus laut dan ombak besar pada bulan tertentu dan mengatasi ancaman serangan hama lumut dan tiram; (2) Meningkatkan dukungan pemerintah melalui sosialisasi kesehatan untuk mengatasi ancaman penyakit gatal-gatal pada pembudi daya dan melalui pelatihan/ penyuluhan peningkatan kualitas produk serta manajemen pasar sehingga mampu menghindari ancaman fluktuasi harga dan jatuhnya harga jual.

\section{4) Strategi WT (Weaknesses - Threats)}

Strategi ST merupakan strategi yang disusun berdasarkan pertimbangan-pertimbangan faktor kelemahan (Weaknesses) yang dimiliki oleh usaha dengan ancaman (Threats) yang datang dari luar usaha yang selanjutnya digunakan untuk mengembang usaha budi daya rumput laut di Pulau Sebatik.

Berdasarkan pertimbangan dari 10 faktor yang ada, dihasilkan 2 alternatif strategi yang layak, yaitu: (1) Pengadaan bibit varietas baru untuk mengatasi serangan hama lumut dan tiram serta mampu bertahan terhadap arus laut dan guncangan ombak yang besar sehingga penyakit gatal-gatal pada pembudi daya yang disebabkan oleh lumut dapat teratasi. Mengoptimalkan kelembagaan pembudi daya sebagai wadah penghubung dengan instansi terkait untuk menetapkan kebijakan tentang standar harga sehingga ancaman fluktuasi harga dan jatuhnya harga jual dapat diatasi. (2) Mengoptimalkan kelembagaan pembudi daya sebagai wadah penghubung dengan instansi terkait untuk menetapkan kebijakan tentang standar harga sehingga ancaman fluktuasi harga dan jatuhnya harga jual dapat diatasi.

Hasil dari perhitungan TAS (Total Attractive Score) menunjukkan bahwa prioritas strategi yang paling terbaik yang dapat dilakukan saat ini adalah meningkatkan dukungan pemerintah melalui sosialisasi kesehatan untuk mengatasi ancaman penyakit gatal-gatal pada pembudi daya dan melalui pelatihan/penyuluhan peningkatan kualitas produk serta manajemen pasar sehingga mampu menghindari ancaman fluktuasi harga dan jatuhnya harga jual dengan nilai TAS tertinggi adalah 6,7566.

Berdasarkan hasil analisis Tabel 6, QSPM tiga pilihan strategi prioritas yang memiliki peringkat tertinggi, antara lain,

1. Meningkatkan dukungan pemerintah dalam kebijakan pemasaran dan perkembangan teknologi.

Usaha budi daya yang ingin berkembang harus ditunjang oleh pangsa pasar yang ideal. Harga pasar rumput laut di Pulau Sebatik yang seringkali terjadi fluktuasi bahkan terjadi penurunan harga yang drastis menyebabkan kurangnya 
pendapatan pembudi daya. Untuk menangani permainan harga oleh pedagang perlu adanya penegasan tentang kebijakan standar harga yang ditetapkan oleh instansi terkait dan diperlukan dukungan pemerintah dalam hal pembentukan lembaga untuk penyediaan saprodi sehingga mempermudah pembudi daya dalam proses produksi, siap membeli hasil panen pembudi daya rumput laut apabila terjadi penurunan harga yang drastis untuk menjaga stabilitas pendapatan pembudi daya dan menjembatani pemasaran hasil produksi rumput laut dengan pihak swasta sesuai standar atau kualitas yang ditetapkan sehingga dapat meningkatkan harga rumput laut. Perkembangan usaha juga ditunjang oleh teknologi yang digunakan, instansi terkait perlu memberikan informasi teknologi terbaru yang dapat digunakan untuk pengembangan usaha.

Peningkatan teknologi budi daya adalah hal yang dibutuhkan pembudi daya untuk meningkatkan produksi rumput laut. Oleh sebab itu, dibutuhkan peran pemerintah untuk memfasilitasi teknologi budi daya yang telah digunakan sebagian pembudi daya rumput laut di luar Pulau Sebatik, contohnya penggunaan pupuk organik khusus untuk rumput laut untuk meningkatkan produksi rumput laut seperti yang telah dicobakan oleh Supriadi (2017).

2. Mengadakan bibit varietas baru yang ditemukan melalui teknologi yang mutakhir untuk penanganan bibit yang kurang sehat

Produkyang berkualitas tinggiadalah nilaijual bagi pembudi daya rumput laut. Untuk menghasilkan produk yang berkualitas tinggi dibutuhkan proses budi daya yang optimal dengan menggunakan alat dan bahan yang berkualitas. Salah satu bahan yang harus diperhatikan kualitasnya adalah bibit rumput laut. Pada saat ini bibit rumput laut yang biasanya digunakan oleh pembudi daya adalah bibit turunan dari rumput laut yang telah ditanam sebelumnya sehingga kadangkala menyebabkan produksi menurun dikarenakan faktor usia rumput laut yang berulang-ulang dijadikan sebagai bibit. Seharusnya, bibit yang digunakan adalah F1 atau yang bersumber dari kultur jaringan. Hal ini sesuai dengan penelitian Pong-Masak et al. (2011); Parenrengi, (2013); Pong-Masak et al. (2013); Pong-Masak dan Parenrengi (2014); Pong-Masak dan Priono (2015); Pong-Masak dan Simatupang (2017); Pong-Masak dan Sarira (2018); serta Parenrengi et al. (2016).

Strategi pengadaan bibit baru hendaknya menjadi bagian penting yang harus dilakukan oleh usaha budi daya rumput laut di Pulau Sebatik. Bibit yang baru dan memiliki keunggulan tersendiri untuk menjamin kualitas produksi dan juga kuantitas produksi. Kualitas produksi rumput laut merupakan langkah yang sangat efektif untuk menjaga kepuasan para konsumen karena sebagian besar konsumen menjadikan kualitas produksi sebagai dasar penetapan harga.

3. Mengoptimalkan ketersediaan tenaga kerja dan ketersediaan lahan yang didukung sumber daya yang terampil.

Lokasi penelitian terletak di Kecamatan

Tabel 6. Hasil Analisis Quantitatif Strategy Planning Matrix (QSPM) dan Peringkat Prioritas Usaha Budi Daya Rumput Laut di Pulau Sebatik.

\begin{tabular}{|c|c|c|c|}
\hline & Alternatif Strategi & TAS & $\begin{array}{l}\text { Skala } \\
\text { Prioritas }\end{array}$ \\
\hline 1. & $\begin{array}{l}\text { Mengoptimalkan ketersediaan tenaga kerja dan ketersediaan lahan yang } \\
\text { didukung sumber daya yang terampil }\end{array}$ & 6,2729 & 3 \\
\hline 2. & $\begin{array}{l}\text { Meningkatkan dukungan pemerintah dalam kebijakan pemasaran dan } \\
\text { perkembangan teknologi }\end{array}$ & 6,7566 & 1 \\
\hline 3 & $\begin{array}{l}\text { Mengadakan bibit varietas baru yang ditemukan melalui teknologi yang } \\
\text { mutakhir untuk penanganan bibit yang kurang sehat }\end{array}$ & 6,7315 & 2 \\
\hline 4 & Mengoptimalkan kelembagaan pembudi daya untuk menciptakan kerjasama & 6,1786 & 6 \\
\hline 5 & Meningkatkan dukungan SDM yang terampil melalui pelatihan dan penyuluhan & 6,2353 & 5 \\
\hline 6 & $\begin{array}{l}\text { Sosialisasi dan penyuluhan kesehatan tentang serangan ubur-ubur di lokasi } \\
\text { budi daya rumput laut yang menyebabkan penyakit gatal - gatal pada pembudi } \\
\text { daya dan cara pencegahannya. }\end{array}$ & 5,9794 & 8 \\
\hline 7 & $\begin{array}{l}\text { Pengadaan bibit varietas baru untuk mengatasi serangan hama lumut dan tiram } \\
\text { serta mampu bertahan terhadap arus laut dan guncangan ombak yang besar. }\end{array}$ & 6,0040 & 7 \\
\hline 8 & $\begin{array}{l}\text { Mengoptimalkan kelembagaan pembudi daya sebagai wadah penghubung } \\
\text { dengan instansi terkait }\end{array}$ & 6,2505 & 4 \\
\hline
\end{tabular}

Sumber: Data Primer Diolah, 2018 
Sebatik Barat dengan jumlah penduduk sebanyak 8.306 jiwa yang terdiri dari 4.430 jiwa berjenis kelamin laki-laki dan 3.876 jiwa berjenis kelamin perempuan dengan rasio jenis kelamin sebesar 114,29. Kecamatan lain yang menjadi tempat penelitian adalah Kecamatan Sebatik dengan jumlah penduduk 4.924 jiwa yang terdiri dari 2.640 jiwa berjenis kelamin laki-laki dan 2.284 jiwa berjenis kelamin perempuan dengan rasio jenis kelamin 115,59. Persentase tingkat pendidikan SD terbanyak adalah $75 \%$ dari keseluruhan jumlah penduduk. Rumah tangga perikanan pada tahun 2017 sebanyak 306 (Dinas Kelautan dan Perikanan Kabupaten Nunukan, 2015). Perbandingan jumlah penduduk pada 2 kecamatan tempat penelitian dengan jumlah pembudi daya rumput laut menunjukkan bahwa potensi peluang tenaga kerja pada usaha budi daya rumput masih sangat besar sehingga berpeluang untuk pengembangan usaha tersebut.

Sumber daya yang terampil dalam usaha budi daya rumput laut adalah modal besar karena pembudi daya yang terampil dapat memanfaatkan tenaga kerja dan lahan secara efisien. Keterampilan sumber daya memanfaatkan ketersediaan lahan menjadi kesempatan bagi pembudi daya untuk memodifikasi jarak tanam rumput laut agar pertumbuhan rumput laut menjadi lebih baik dengan optimalnya arus laut dan ombak yang mengenai rumput laut. Untuk mendukung optimalisasi ketersediaan tenaga kerja dan ketersediaan lahan perlu memperhatikan pengembangan sumber daya agar lebih terampil dalam proses budi daya rumput laut. Hal ini sesuai dengan penelitian Santoso et al. (2015).

Soekartawi (2011) menyatakan bahwa tingkat pendidikan seseorang dapat mengubah pola pikir dan daya penalaran yang lebih baik sehingga semakin lama atau semakin tinggi seseorang mengenyam pendidikan akan semakin rasional dalam mengelola usahanya dan relatif lebih cepat menanggapi perkembangan teknologi, sedangkan apabila tingkat pendidikan rendah maka agak sulit untuk mengadopsi inovasi dengan cepat.

Adapun hal-hal yang perlu diperhatikan dalam pengembangan sumber daya pada usaha budi daya rumput laut, antara lain,

a) pembudi daya perlu ikut pelatihan-pelatihan tentang manajemen budi daya rumput laut yang benar atau cara menghasilkan produksi yang berkualitas baik; b) pembudi daya perlu ikut pelatihan atau sosialisasi inovasi teknologi yang dilakukan oleh ahli teknologi yang mendukung pengembangan usaha budi daya rumput laut untuk mendapatkan informasi terbaru tentang teknologi budi daya rumput laut yang digunakan;

c) pembudi daya perlu mengikuti pelatihan tentang strategi pengurangan biaya dalam sebuahusayauntukmeningkatkan pendapatan walaupun tidak terjadi peningkatan jumlah produksi.

Penelitian sebelumnya tentang pentingnya kegiatan pelatihan pada kelompok budi daya rumput laut telah banyak dilakukan dan hasilnya berdampak pada peningkatan usaha dan kesejahteraan pembudi daya rumput laut (Nurwidodo et al., 2018; Purnomowati, R., 2015; dan Patang, 2014). Secara keseluruhan, hasil penelitian tentang strategi pengembangan rumput laut di Pulau Sebatik selaras dengan hasil penelitian (La Hadifa et al., 2017; dan Loura Pandelaki, 2012).

\section{PENUTUP}

Berdasarkan hasil analisis dan pembahasan yang telah diuraikan, maka dapat disimpulkan bahwa pengembangan usaha budi daya rumput laut di Pulau Sebatik layak untuk dijalankan dan dikembangkan. Strategi yang menjadi prioritas adalah meningkatkan dukungan pemerintah dalam kebijakan pemasaran dan perkembangan teknologi, mengadakan bibit varietas baru, mengoptimalkan ketersediaan tenaga kerja terampil, serta ketersediaan lahan.

\section{UCAPAN TERIMA KASIH}

Ucapan terima kasih kepada Rektor, Direktur Program Pascasarjana Universitas Muhammadiyah Parepare, serta dosen pembimbing tesis atas segala bantuannya mulai dari proses penelitian sampai pada publikasi hasil peneltian ini.

\section{PERNYATAAN KONTRIBUSI PENULIS}

Dengan ini kami menyatakan bahwa kontribusi masing-masing penulis terhadap pembuatan karya tulis adalah Syafrianto Sarmin sebagai kontributor utama/penulis pertama, Muhammad Siri Dangnga sebagai kontributor anggota, dan Andi Adam Malik sebagai kontributor utama/penulis korespondensi. Penulis menyatakan bahwa telah melampirkan surat pernyataan kontribusi penulis. 


\section{DAFTAR PUSTAKA}

Paramita, A, \& Syachbrani, W. (2019). Nilai keekonomian usaha rumput laut di Sulawesi Selatan. Seiko: Journal of Management \& Business, 2(2), 1-12. https://doi.org/10.37531/sejaman.v2i2.704

Al-Amin. (2011). Strategi pengembangan berkelanjutan budi daya rumput laut eucheuma cottonii di Kabupaten Barru. Universitas Hasanuddin.

Antowijoyo, Tarmaji, Yuliyanto, Yulianti Prihatiningrum, \& Fifi Swandari. (2017). Kelayakan usaha budi daya rumput laut eucheuma cottonii dengan metode longline. Jurnal Wawasan Manajemen, 5(1), 73-88. http://dx.doi.org/10.20527/jwm. v5i1.108

Arikunto, S. (2002). Prosedur penelitian, suatu pendekatan praktek. PT. Rineke Cipta.

Departemen Kelautan dan Perikanan. (2006). Strategi pembangunan kelautan dan perikanan 2007. Departemen Kelautan dan Perikanan.

Dinas Kelautan dan Perikanan Kabupaten Nunukan. (2015). Statistik kelautan dan perikanan Kabupaten Nunukan tahun 2014. Pemerintah Kabupaten Nunukan. $128 \mathrm{hlm}$.

Hadifa, L., Rianda, L., \& Sara, L. (2017). Analisis kendala dan strategi pengembangan usaha rumput laut di Kabupaten Konawe Selatan. Jurnal Sosio Agribisnis (JSA), 2(1), 1-11. http:// dx.doi.org/10.33772/jsa.v2i1.7948

Hartati, S. (2003). Kajian pemberdayaan petani rumput laut dan kontribusinya terhadap kesejahteraan masyarakat pesisir di Pulau Panggang [Tesis, Program Pascasarjana Institut Pertanian Bogor].

Irmayani, Yusuf, S., \& Nispar, M. (2014). Analisis kelayakan usaha budi daya rumput laut di Desa Mallasoro Kecamatan Bangkala Kabupaten Jeneponto. Jurnal Bisnis Perikanan, 1(1), 17-28.

Kailola, W. M., Helminuddin, \& Abdunnur. (2016). Analisis usaha budi daya rumput laut di wilayah pesisir. http://dx.doi.org/10.13140/RG.2.2.11848.52485

Kementerian Kelautan dan Perikanan (KKP). (2015). Potensi dan volume produksi rumput laut Indonesia 2014. Kementerian Kelautan dan Perikanan.

Keputusan Menteri Kelautan dan Perikanan No.KEP.32/ MEN/2010. http://jdih.kkp.go.id/peraturan/per-12men-2010.pdf

Lukman, H., Patang, P., \& Lahming, L. (2019). Studi kelayakan usaha budi daya rumput laut (gracillaria sp.) di Desa Paria Kecamatan Duampanua Kabupaten Pinrang. Jurnal Pendidikan Teknologi Pertanian, 5(2), 43-54.

Marak, H. K., Sundji, \& Paulus, C., A. (2018). Analisis finansial usaha budi daya rumput laut dengan metode longline di Desa Kaliuda Kecamatan Pahunga Lodu Kabupaten Sumba Timur. Jurnal Aquatik, 1(1), 24-33.

Ngamel, A. K. (2012). Analisis finansial usaha budidaya rumput laut dan nilai tambah tepung karaginan di Kecamatan Kei Kecil, Kabupaten Maluku Tenggara. Jurnal Sains Terapan, 2(1), 39-47. https://doi.org/10.29244/jstsv.2.1.39-47

Nur, D., Rustam, \& Asni, A. (2019). Pemberdayaan masyarakat pesisir dalam peningkatan pendapatan melalui kegiatan budi daya rumput laut kappaphycus alvarzii di Kabupaten Bulukumba. Jurnal IImiah Agrisains, 20(1), 18-25.

Nurdin, M. F., Laapo, A., \& Howara, D. (2013). Strategi pengembangan usaha budidaya rumput laut di Desa Lalombi Kecamatan Banawa Selatan Kabupaten Dongala. Jurnal Agrotekbis, 1(2), 192-197.

Nurwidodo, Rahardjanto A, Husamah, \& Mas'odi. (2018). Pendampingan masyarakat dalam budidaya rumput laut di Kepulauan Sapeken Kabupaten Sumenep Jawa Timur. International Journal of Community Service Learning, 2(3), 157-166. http://dx.doi.org/10.23887/ijcsl.v2i3.14770

Pandelaki, L. (2012). Strategi pengembangan budi daya rumput laut di Pulau Nain Kabupaten Minahasa Utara. Jurnal Perikanan dan Kelautan Tropis, 8(2), 52-57. https://doi.org/10.35800/ jpkt.8.2.2012.420

Patang. (2014). Strategi pengembangan rumput laut (kappahycus alvarezii) di Kecamatan Mandalle Kabupaten Pangkep. Jurnal Galung Tropika, 3(1), 51-63. http://dx.doi.org/10.31850/jgt.v3i1.62

Parenrengi, A. (2013). Seaweed culture in Indonesia. Indonesia-FAO regional workshop on seaweed culture, handling, and processing 3-6 October 2013.

Parenrengi, A., Fahrur, Makmur, \& Mulyaningrum, S. R. H. (2016). Seleksi rumput laut kappaphycus striatum dalam upaya peningkatan laju pertumbuhan bibit untuk budidaya. Jurnal Riset Akuakultur, 11(3), 235-248. http://dx.doi.org/10.15578/ jra.11.3.2016.235-248

Pasaribu, A. M., Yusuf, D., Amiluddin. (2005). Pengantar perencanaan dan evaluasi proyek perikanan. Gajah Mada University Press.

Pong-Masak, P. R, Parenrengi, A., Suryati, E., \& Rachmansyah. (2011). Protokol seleksi varietas bibit unggul rumput laut. Balai Riset Perikanan Budidaya Air Payau, Pusat Penelitian dan Pengembangan Perikanan Budidaya, Badan Penelitian dan Pengembangan Kelautan dan Perikanan. 27 halaman. 
Pong-Masak, P. R., Priono, B., \& Insan, I. (2011). Seleksi klon bibit rumput laut, glacilaria verrucosa. Media Akuakultur, 6(1), 1-12. http://dx.doi. org/10.15578/ma.6.1.2011.1-12

Pong-Masak, P. R., Parenrengi, A., \& Tjaronge, M. (2013). Produksi bibit unggul rumput laut kappaphycus alvarezii. Rekomendasi Teknologi Kelautan Perikanan. Balitbang KP, KKP, 160-175.

Pong-Masak, P. R., Kristanto, A. H., Kusdiarti, \& Kusnendar, E. (2014). Peningkatan produktivitas dan keuntungan budidaya rumput laut kappaphycus alvarezii menggunakan bibit unggul hasil seleksi varietas. Prosiding Forum Inovasi Teknologi Akuakultur, 6-8 Mei 2014, 123-132.

Pong-Masak, P. R., \& Parenrengi, A. (2014). Petunjuk teknis produksi bibit unggul rumput laut kappaphycus alvarezii dengan metode seleksi varietas. LP2BRL, Balitbang KP, KKP, 32 halaman.

Pong-Masak, P. R., \& Priono, B. (2015). Pengembangan bibit rumput laut kappaphycus alvarezii dengan metode seleksi varietas di Boalemo, Gorontalo. Prosiding Forum Inovasi Teknologi Akuakultur, 8-9 Juni 2015, 727-737.

Pong-Masak, P. R., \& Simatupang, N. F. (2017). Penerapan seleksi varietas untuk produksi bibit unggul rumput laut eucheuma denticulatum di Perairan Kupang, Nusa Tenggara Timur.Prosiding Seminar Nasional Tahunan XIV: Hasil Penelitian Perikanan dan Kelautan, UGM, 141-149.

Pong-Masak P. R, \& Sarira, N. H. (2018). Seleksi rumput laut kappaphycus alvarezii (rhodophyceae) dalam upaya penyediaan bibit unggul untuk budidaya. Jurnal Perikanan Universitas Gadjah Mada, 20(2), 79-85. https://doi.org/10.22146/jfs.36109

Purnomowati, R. (2015).Pengaruh pengembangan budidaya rumput laut terhadap kesejahteraan masyarakat pesisir di pesisir timur Pulau Lombok Provinsi NTB (Studi kasus Desa Pemongkong - Kecamatan Keruak). Jurnal Agribisnis, 9(1), 37-48. https://doi.org/10.15408/aj.v9i1.5067

Putri, D, Sayekti W. D, \& Rosanti N. (2014). Analisis pendapatan dan strategi pengembangan budidaya rumput laut di Pulau Pahawang Kecamatan Punduh Pidada Kabupaten Pesawaran. Jurnal IImu IImu Agribisnis, 2(1), 56-63. http://dx.doi. org/10.23960/jiia.v2i1.561

Radiarta, N., Erlania, Haryadi, J., \& Rosdiana, A. (2016). Analisis pengembangan budi daya rumput laut di Pulau Analysis of Seaweed Aquaculture Development in Sebatik Island, Nunukan Regency, North Kalimantan. Jurnal Kebijakan Perikanan Indonesia 8(1), 29-40. http://dx.doi. org/10.15578/jkpi.8.1.2016.29-40
Rangkuti, F. (2008). Analisis SWOT teknik membedah kasus bisnis: Reorientasi konsep perencanaan strategi untuk menghadapiabad 21. PT. Gramedia Pustaka Utama.

Risdiansyah, T. (2011). Analisis kelayakan ekonomi budi daya rumput laut di Pesisir Kabupaten Jepara [Skripsi, Jurusan Ekonomi Pembangunan Fakultas Ekonomi Universitas Negeri Semarang]. https://lib.unnes.ac.id/5205/1/7623.pdf

Riyanto, B. (2010). Dasar-dasar pembelanjaan perusahaan (Ed. 4). BPFE.

Reski. (2013). Dampak pengembangan budi daya rumput laut di Kabupaten Nunukan tahun 2012 [Tugas Akhir, Program Magister, Universitas Terbuka]. UT Repository. http://repository.ut.ac. id/962/1/41553.pdf

Santoso, R., Wahyudi, D., \& Hafid, A. (2015). Strategi Pengembangan Rumput Laut Di Kecamatan Talango Kabupaten Sumenep. Jurnal Pertanian Cemara, 12(1). 14-19. https://doi.org/10.24929/ fp.v12i1.195

Shafitri, N., Zulham, A., \& Muawanah, U. (2020). Masyarakat pesisir dan perilakunya terhadap jaringan usaha perikanan: Studi kasus daerah perbatasan di Kabupaten Nunukan. Buletin IImiah Marina Sosial Ekonomi Kelautan dan Perikanan 6(1), 61-71. http://dx.doi.org/10.15578/marina. v6i1.8721.

Soekartawi. (2003). Analisis usaha tani. Universitas Indonesia Press.

Supriadi. (2017). Pengaruh dosis pupuk organik cair sargassumpada perendaman thallusterhadaplaju pertumbuhan dan produksi rumput lauteucheuma cottonii [Skripsi, Program Studi Budi Daya Perairan, Fakultas Pertanian, Peternakan dan Perikanan, Universitas Muhammadiyah Parepare].

Suryawati, S. H., \& Erlina, M. D. (2017). Strategi pengembangan usaha budidaya rumput laut di Kabupaten Buton Selatan. Jurnal Sosial Ekonomi Kelautan dan Perikanan, 12(1), 31-44. http:// dx.doi.org/10.15578/jsekp.v12i1.6286

Wahyuni, A. P., Fattah, N., \& Anita. (2021). Analisis kelayakan usaha budi daya rumput laut eucheuma spinosum. Jurnal Tarjih: Fisheries and Aquatic Studies, 1(1). https://jurnal-umsi.ac.id/index.php/ fisheries/article/view/228/18

Wijaya, R. A., \& Sari, Y. D. (2018). Peran usaha budi daya rumput laut dalam pengentasan kemiskinan di Pulau Nunukan. Seminar Nasional Sosial Ekonomi Kelautan dan Perikanan, 451-461. Balai Besar Riset Sosial Ekonomi Kelautan dan Perikanan. 